\title{
The role of alexithymia and mindfulness in predicting depression and anxiety in women with cancer
}

\author{
Mohammad Narimani ${ }^{1}$, Setareh $\mathrm{Jani}^{2}$, Roonak Rezaei ${ }^{3}$ \\ 1-Professor, Department of Psychology, University of Mohaghegh Ardabili, Ardebil, Iran. \\ 2- PhD Student of Psychology, Department of Psychology, University of Mohaghegh Ardabili, Ardabil, Iran \\ (Corresponding Author). E-mail: jani_s11@yahoo.com \\ 3- Master of Clinical Psychology, Kurdistan University of Medical Sciences, Sanandaj, Iran.
}

Received: 10/11/2019 Accepted: 12/02/2020

\begin{abstract}
Introduction: Depression and anxiety in cancer patients are associated with a variety of cognitive and personality variables such as alexithymia and mindfulness.

Aim: The present study aimed to investigate the role of alexithymia and mindfulness in predicting depression and anxiety in women with cancer.

Method: The research method is correlational and predictive. The statistical population consisted of all female patients with cancer covered by Arezoo Charity Institute in Pars Abad (1979). 120 women with cancer were selected through purposive sampling from the statistical population and participated in this study. The data were collected using Toronto Alexithymia Scale (TAS-20), Mindful Attention Awareness Scale (MAAS) and Hospital Anxiety and Depression Scale (HADS), and analyzed by SPSS-20 software, Pearson correlation coefficient and stepwise regression analysis.

Results: The findings of this study showed that alexithymia and mindfulness can predict depression and anxiety in women with cancer significantly $(\mathrm{P}<0.01)$.

Conclusion: Alexithymia and mindfulness are important factors in the depression and anxiety of cancer patients. Therefore, it is necessary to emphasize psychological interventions focused on these variables in educational, prevention and treatment programs of these patients.
\end{abstract}

Keywords: Alexithymia, Anxiety, Cancer, Depression, Mindfulness

How to cite this article : Narimani M, Jani S, Rezaei R. The role of alexithymia and mindfulness in predicting depression and anxiety in women with cancer. Shenakht Journal of Psychology and Psychiatry. 2020; 7 (1): 78-89 .URL: http://shenakht.muk.ac.ir/article-1-867-fa.pdf

Copyright @ 92018 the Author (s). Published by Kurdistan University of Medical Sciences. This is an open access article distributed under the terms of the Creative Commons Attribution-Non Commercial License 4.0 (CCBY-NC), where it is permissible to download, share, remix, transform, and buildup the work provided it is properly cited. The work cannot be used commercially without permission from the journal. 


\title{
نقش ناكويى هيجانى و ذهن آكاهى در ييشبينى افسردىى و اضطراب زنان مبتلا به سرطان
}

\author{
محمد نريمانى '، ستاره جانى '، روناكى رضائى \\ 1.ا.استاد، كروه روان شناسى، دانشكاه محقق اردبيلى، اردبيل، ايران.

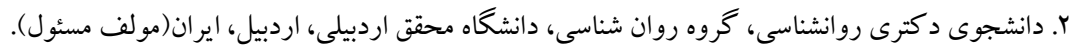 \\ ايميل:yani_s11@yahoo.com \\ r. كارشناسى ارشد روانشناسى بالينى، كروه آموزشى روانشناسى بالينى، دانشكاه علوم يزشكى كردستان، سندج، ايران.
}

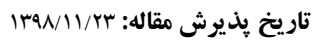

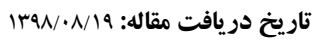

جكيده

مقدمه: افسردگى و اضطراب بيماران مبتلا به سرطان با متغيرهاى شخصيتى و شناختى متعددى از جمله ناكويى هيجانى و ذهن آكاهى در ارتباط است.

هدف: هدف يُزوهش حاضر بررسى نقش ناكويى هيجانى و ذهن آكاهى در ييشينى افسردگى و اضطراب زنان مبتلا به سرطان انجام

روش: روش يُزوهش حاضر، همبستگى و از نوع بيش بينى است. جامعه آمارى شامل كليه بيماران زن مبتلا به سرطان تحت بوشش

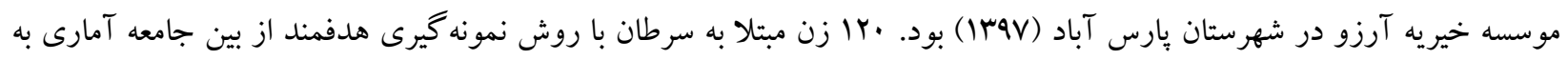

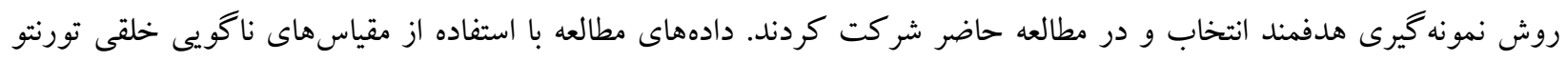

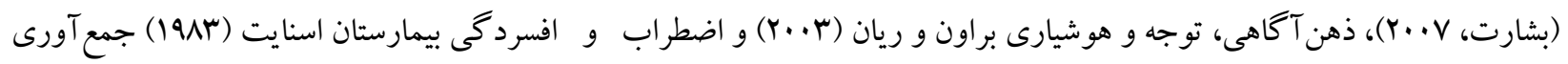

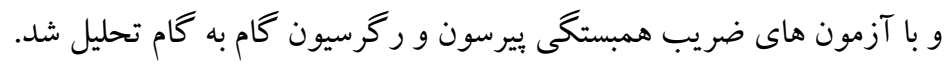
يافته ها: يافتهاى ئزوهش حاضر نشان داد كه ناگويى هيجانى و ذهن آكاهى قادر هستند تا افسردگى و اضطراب زنان مبتلا به سرطان

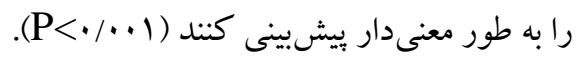
نتيجه كيرى: ناكويى هيجانى و ذهن آكاهى از عوامل مهم دخيل در افسردگى و اضطراب بيماران مبتلا به سرطان مىباشند؛ بنابراين

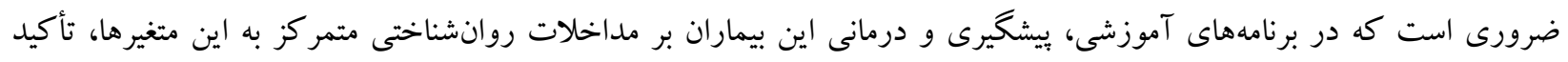
كردد. كليد وازهها: اضطراب، افسردگى، سرطان، ذهن آكاهى، ناگويى هيجانى 


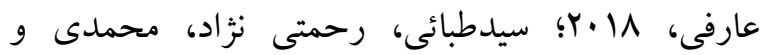
مقدمه

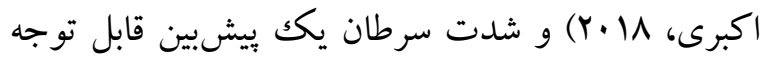
از نمره ناكويى هيجانى است (مادو گال، هان، شاكارا

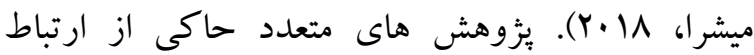

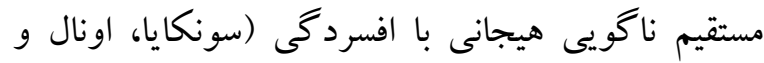

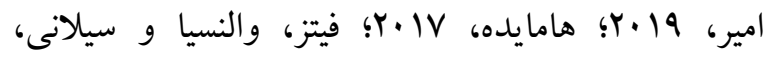
1イ

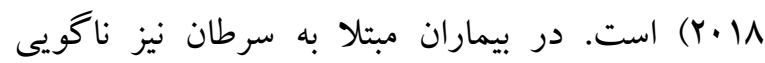
هيجانى با كاهش ساز گارى هيجانى (مارازو، سيدلى،

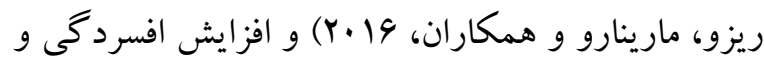

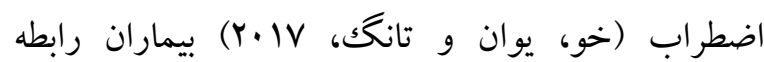

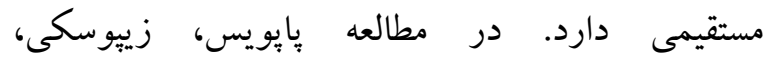
بارجكويس و جلينسيس (1) (Y) آن دسته از بيماران مبتلا به سرطان سينه كه ناكويى هيجانى بالايى داشتند نسبت به بيمارانى كه معيارهاى تشخيصى ناكويى هيجانى رانى برآورده نمى كردند، نشانهاى افسردگى و اضطراب بيشترى داشتند. در مطالعه اكانلى، كارابولوتلو، آسى

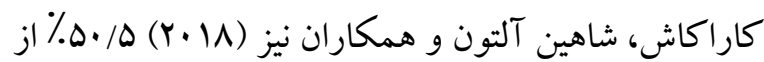
بيماران مبتلا به سرطان داراى ناگويى هيجانى بودند كه اين بيماران نسبت به افراد ديخر نتايج منفى بيمارى خود را بيشتر دركك مى كردند و احساسات منفى آنها در مورد بيما

$$
\text { بيمارى شديدتر بود. }
$$

يكى ديخر از متغيرهايى كه با اضطراب و افسردكى ارتباط دارد، ذهن آكاهى است. ذهن آكاهى به عنوان حالت توجه برانگيخته و آكاهى از آنجه كه در لحظه كنونى اتفاق مىافتد تعريف شده است كه به فرد امكان مىدهد تا به جاى آنكه به رويدادها به طور غيرارادى و

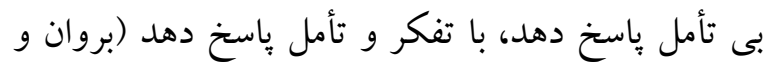

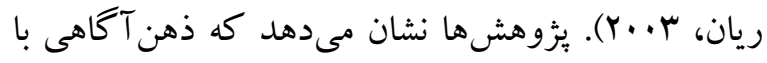

سرطان' نوعى بيمارى است كه با رشد كنترل نشده سلولى مهلى و تهاجم به بافتهاى موضعى سيستماتيك مشخص مى مى

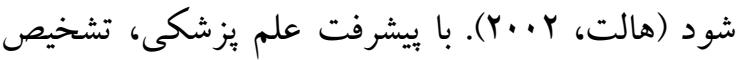
سرطان برابر مرگك حتمى و قريبالوقوع نيست؛ اما صرف تشخيص، باعث ايجاد مشكلات عاطفى و هيجانى عميق مانند اضطراب و افسردگى در بيماران مى گردد (حيدرى راد، ياراحمدى، حيدرى راد و شفايى، Y) (Y).

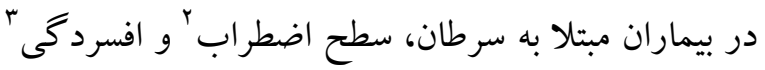
بيماران، قابل توجه و حائز اهميت بالينى است. (ميليخان،

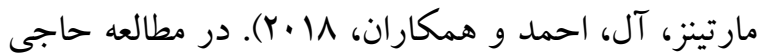
سيد طبايى، رحمتى نزاد و صحت (10 (Y) علائم

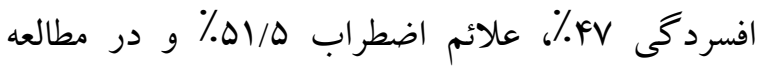
جيمز -فونسكا، كالدرون، هرناندز، رامون و همكاران

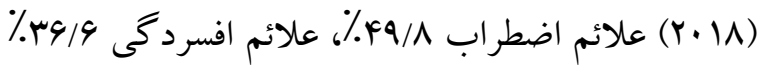

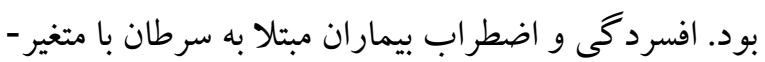
هاى شخصيتى و شناختى متعددى از جمله ناكويى هيجانى و ذهن آكاهى در ارتباط است. ناكويى هيجانى سازهاى است متشكل از دشوارى در شناسايى احساسها، دشوارى در توصيف آنها و جهت گيرى فكرى بيرونى. عقيده بر اين است كه ناگويى هيجانى عاملى خطرساز براى بسيارى از اختلالهاى روانيزشكى است؛ زيرا افراد مبتلا به اين عارضه بسيار سخت تحت فشارهاى جسمانى هيجانهايى هستند كه به كلام در نمى آيند. اين نارسايى ليى مانع تنظيم هيجانها مىشود و ساز كارى موفقيت آميز را

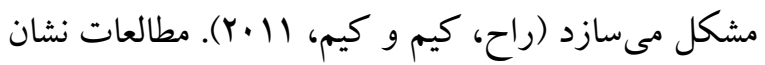
مىدهد كه بين ناكويى هيجانى بيماران مبتلا به سرطان و افراد سالم تفاوت معنادارى وجود دارد (معتمدى و

\footnotetext{
1 - Cancer

2- Anxiety

3- Depression
} 
كيفيت زندگى اين بيماران مشكلاتى ايجاد كند، بررسى عوامل مرتبط با افسردگى و اضطراب اين بيماران حائز اهميت است و كمكك خواهد كرد تا مداخلات روانشناختى مهمى را در جهت افزايش عوامل روانى مانند اميد، خوشينى و ارتقا سطح سلامت اين بيماران و بيشخيرى و درمان افسردگى و اضطر اب اين بيماران داشته باشيم. علاوه بر اين، انجام اين مطالعه در بافت فرهنگى دردي

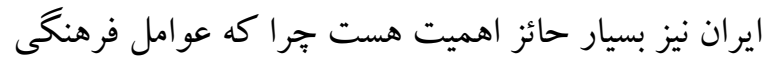
در اضطراب و افسردگى افراد، اهميت خاصى دارد؛ بنابراين مطالعه حاضر در يى آن است تا روشن كند كه آيا مىتوان افسردگى و اضطراب زنابن مطان مبتلا به سرطان در

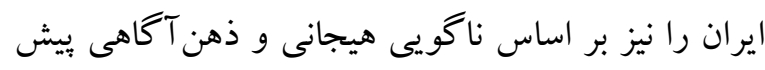
بينى كرد يا خير؟

روش

روش يززوهش حاضر، همبستخى و از نوع بيشبينى بود. جامعه آمارى شامل كليه بيماران زن مبتلا به سرطان تحت بوشش موسسه خيريه آرزو در شهرستان بارس آباد (IrqV) بود (N=FYA). در تحقيقات همبستكى

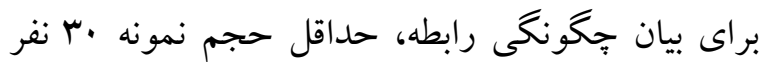

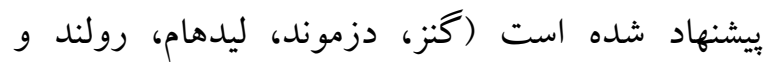

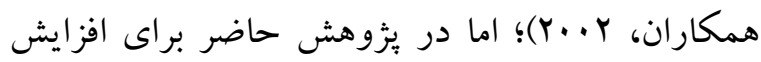

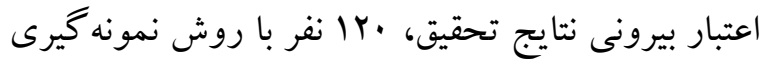

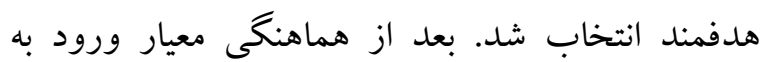
يثزوهش شامل محدوده سنى 11 - .9 سال، كذشت حداقل 9 ماه از تشخيص بيمارى، داشتن تحصيلات حداقل سيكل براى پِاسخ به برسشنامهها، عدم سابقه

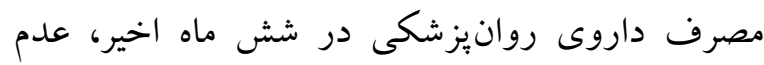

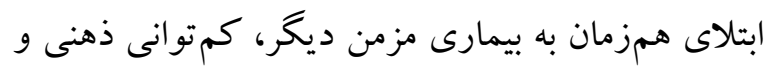
عدم سوءمصرف مواد بود كه از طريق يرونده بيمار و
اضطراب و افسردگى رابطه معكوس معنىدار دارد (ماير، يولاكك و رمرسوال، 19 (Y). در بيماران مبتلا به سرطان نيز ذهن آكاهى كمتر، بيشبين معنىدارى براى اختلالات هيجانى و علائم روانشناختى مانند افسردگى و اضطراب

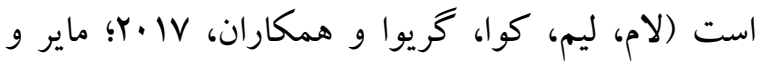

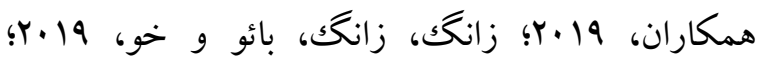

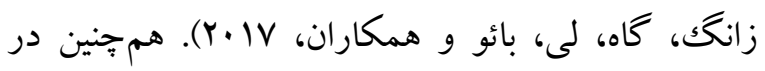
يُزوهشهاى متعدد، تأثير درمان مبتنى بر ذهن آكاهى بر كاهش افسردگى و اضطراب يس از زايمان (شولمن، دئو ك، ريان و برئو و همكاران، 1) (Y)، كاهش اضطراب

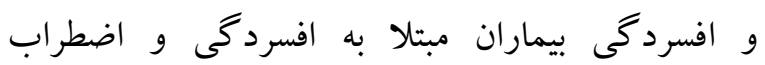

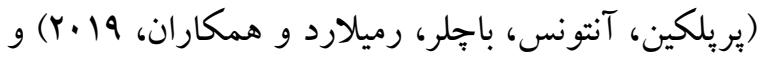
كاهش افسردگى و اضطراب زنان مبتلا به سرطان

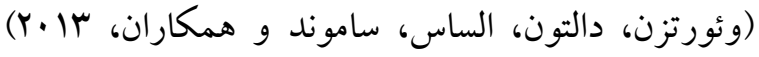
نشان داده است. مطالعه حاجى سيد جوادى، تاجيككزاده، بيات، اشراقى و همكاران (Y) (Y) نيز نشان داد كه درمان مبتنى بر ذهن آكاهى بر كاهش افسردگى و اضطراب بيماران مبتلا به سرطان، مؤثرتر از درمان فراشناختى است. با وجود اينكه سابقه يُزوهشى مطالعه حاضر نشان مىدهد كه افسردگى و اضطراب بيماران مبتلا به سرطان توسط ذهن آكاهى و ناكويى هيجانى ارتباط دارد؛ اما تعداد اين گونه مطالعات محدود هست كه تعداد اين مطالعات، در كشور ما بسيار محدودتر است. با توجه به اينكه در حال حاضر با افزايش شانس زنده ماندن بيماران مبتلا به سرطان در نتيجه تحولات در درمان، كاهش مشكلات عملكردى و و افزايش كيفيت زندگى اين بيماران، در سطح جهانى بيش از بيش اهميت يافته است و درمان نشدن اين علائم مى-

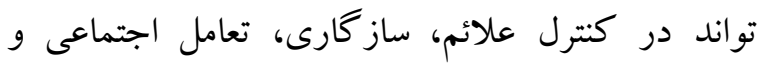


همزمان اين مقياس نيز برحسب همبستكى بين زير مقياس هاى آزمون و مقياسهاى هوش هيجانى، بهزيستى روانشناختى و درماندگى روانشناختى بررسى و تأييد

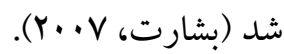
يرسشنامه ذهن آكاهى، توجه و هوشيارى! اين آزمون توسط براون و ريان (س...Y) طراحى شده است. اين

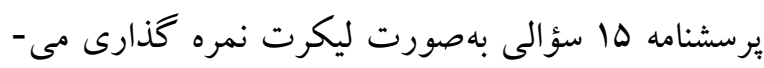
4. شود. حداقل نمره ذهن آكاهى 10 و و حداكثر آن است. روايى اين مقياس مطلوب است (براون و ريان،

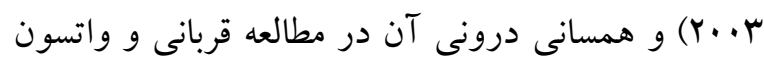

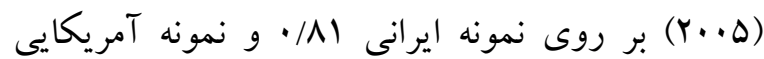
1Ar • گ ₹زارش شده است (عرب قائنى، هاشميان، مجتبائى،

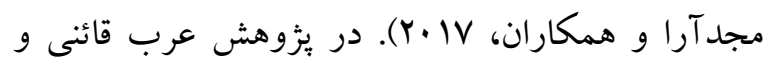
همكاران (Y.lV) نيز مقدار آلفاى كرونباخ •^/ • بود. مقياس اضطراب و افسردمى بيمارستان" اين ابزار توسط

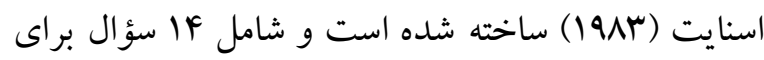
سنجش افسردگى (V سؤال) و اضطراب (V سؤال) در بيماران جسمى، روانى و حتى افراد سالم است. هر سؤال به وسيله يكك مقياس جهار نمرهاى امتيازدهى مىشود.

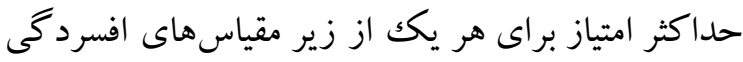
و اضطراب | است. امتياز بالاى |لا در هر دو زمينه

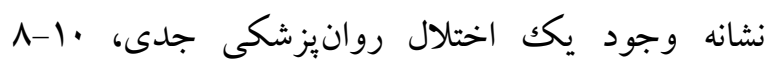
بينابينى و V- · طبيعى محسوب مىشود. يايايى برسشنامه بر حسب آلفاى كرونباخ براى هر يكك از زير مقياسهاى اضطراب و افسردگى در نمونه بالينى ايرانى به ترتيب

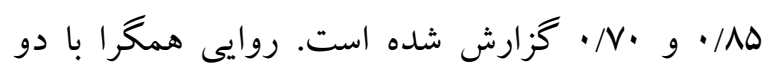
يرسشنامه اضطراب و افسردگى بك براى زير مقياس

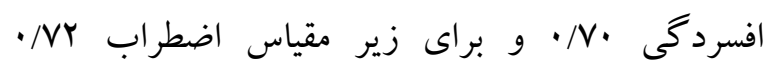

2. Mindful Attention Awareness Scale (MAAS)

${ }^{3}$ - Hospital Anxiety and Depression Scale (HADS)
خود گزارشى آنها مورد بررسى قرار گرفت. يّ از توضيحات لازم به بيماران و كسب رضايت از بيماران، يرسشنامهها اجرا شد. براى اجراى يزوهش و جمع آورى

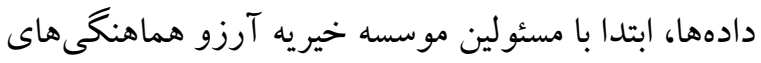
لازم به عمل آمد، سيس با بررسى يروندههاى بيماران تحت بوشش و سيس با تماس با بيمارانى كه معيارهاى اوليه مطالعه را بر آورده مى كردند، آن دسته از بيمارانى كه معيارهاى يزوهش را بر آورده مى كردند و هم جنين تمايل به شركت در بُزوهش را داشتند با روش نمونه كيرى هدفمند به عنوان نمونه نهايى انتخاب شدند ورد برسشنامها بر روى ايشان اجرا شد.

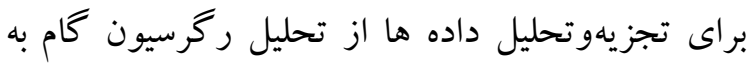
كام استفاده شد و داده ها با بيست و دومين ويرايش نرم افزار SPSS مورد تحليل قرار كرفت.

ابزار مقياس ناعويي خلقى تورنتو': يكك آزمون ·r سؤالى است كه سه زير مقياس دشوارى در تشخيص احساسها، دشوارى در توصيف احساسها و تفكر عينى را در اندازه ينج درجهاى ليكرت از نمره ا تا نمره ه مىسنجد. در نسخه فارسى اين مقياس، ضرايب آلفاى كرونباخ براى ناكويى هيجانى كل و سه زير مقياس دشوارى در تشخيص احساسها، دشوارى در توصيف احساسها و

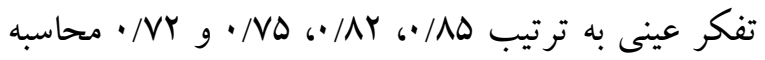
شد كه نشانه همسانى درونى خوب مقياس است. بايايى GV بازآزمايى مقياس ناكويى خلقى-Y.r در يكك نمونه

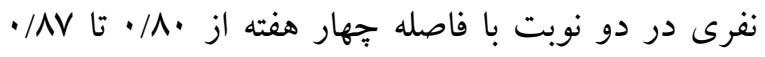
براى ناگويى هيجانى كل و زير مقياسها تأييد شد. روايى

\footnotetext{
1. Toronto Alexithymia Scale (TAS-20)
} 


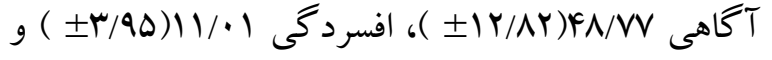

$$
\text { اضطراب (IF/FF) ( }
$$

كزارش شده است (كاويانى، صيفوريان، شريفى و ابراهيم

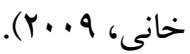

براى تعيين رابطه ناگويى هيجانى و ذهن آكاهى با

افسردكى و اضطراب از ضريب همبستخى ييرسون

استفاده شد كه نتايج آن در جدول ادرج شدره است است

\section{يافتهها}

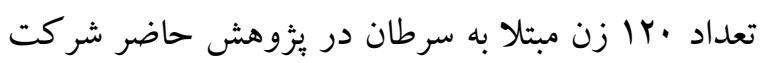
داشتند كه ميانگين (انحراف معيار 士 ) متغيرها در آنها به شرح زير بود: ناكويى هيجانى

\begin{tabular}{|c|c|c|c|c|}
\hline (₹) & $(\boldsymbol{r})$ & (r) & (1) & متغيرها \\
\hline & & & 1 & (1) ناكويى هيجانى \\
\hline & & 1 & $-\cdot / r \cdot *$ & (r) ذهن آكاهى \\
\hline & 1 & $-\cdot / \mu r^{* * *}$ & $\cdot / \Gamma r^{* *}$ & (r) افسردگى \\
\hline 1 & $\cdot / r 9^{* *}$ & $-\cdot / \mu F^{* *}$ & $\cdot / \mu^{* *}$ & (ع) اضطراب \\
\hline
\end{tabular}

از تحليل رگرسيون جند گانه گام به گام استفاده شد كه

براى تحليل بيشتر دادهها و جهت تعيين سهم ناكويى نتايج آن در جدول r و سارائه شده است. هيجانى و ذهن آكاهى در بيشبينى افسردگى و اضطراب

\begin{tabular}{|c|c|c|c|c|c|c|c|c|c|c|c|}
\hline دارى & $\mathbf{t}$ & Beta & خطاى & B & مارى & F & خطاى معيار & $\begin{array}{c}\text { R } \\
\text { اصلاح شده }\end{array}$ & $\mathbf{R}^{2}$ & $\overline{\mathbf{R}}$ & متيشين هاى \\
\hline$\cdot / \ldots$ & $r / q$. & & $\cdot / \cdot M F$ & ו ו & $\cdot / \ldots$ & $1 D / Y F$ & $F / F A$ & $\cdot / 1 \cdot V$ & $\cdot / l l f$ & גזr/ & كام ا \\
\hline$\cdot / \cdot r$ & $-r / 10$ &.$- / 499$ &.$/ . r Y$ & $-\cdot / 1$ & $\cdot / \cdots$ & $1 \% / 19$ & $F / M Y$ &.$/ I V$ & $\cdot / M A F$ & - Arq & كام r \\
\hline
\end{tabular}

كام Y-متغير بيش بين: ناكويى هيجانى و ذهن آكاهى كام 1- متغير بيش بين: ناكويى هيجانى

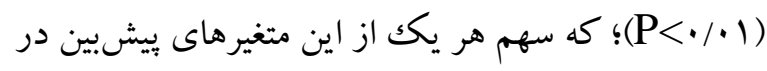

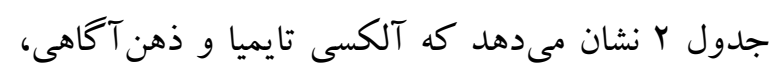

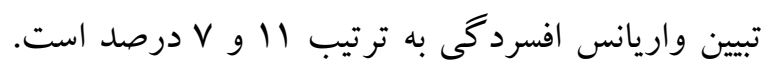
افسردگى را به طور معنىدار، معنى دار بيشبينى مى كنند

جدول rنتايج تحليل ركرسيون جند مانه اضطراب بر اساس ناكويى هيجانى و ذهن آكاهى

\begin{tabular}{|c|c|c|c|c|c|c|c|c|c|c|c|}
\hline مارى & $\mathbf{t}$ & Beta & خطاى معيار & B & مارى & $\mathbf{F}$ & خطاى معيار & $\begin{array}{c}\mathbf{R} \\
\text { اصلاح شده }\end{array}$ & $\mathbf{R}^{2}$ & $\overline{\mathbf{R}}$ & متيشيين \\
\hline$\cdot / \ldots$ & $-F / \cdot 1$ & $-\cdot$ / KFG &.$/ \mu$ & $-\cdot / / r \cdot$ & $\cdot / \cdots$ & $\cdot 1 / 19$ & $F / 11$ &.$/ 11 r$ &.$/ T r$ & . TKG & كام 1 \\
\hline$\cdot / \cdot r F$ & $r / 91$ & $\cdot / T \Delta \Delta$ & $\cdot / \cdot r_{1}$ &.$/ .94$ & $\cdot / \ldots$ & $\mid r / . r$ & $r / . \Delta$ &.$/ 191$ & . MAr & . KFY & كام r \\
\hline
\end{tabular}


هيجانات منفى مىشود. بيمارانى كه قادر به شناسايى هيجانات منفى و تنظيم آن نيستند مشكلات زيادى را در زمينه سازكارى بهتر با شرايط استرسزاى بيمارى تجربه خواهند كرد. علاوه بر اين، در اين بيماران دشوارى در شناسايى و توصيف هيجان با متغيرهايى نظير رفتارهاى غير انطباقى بيمارى و حساسيت بالا نسبت به تجربه درد و استفاده از راهبردهاى مقابلهاى ناسالم براى مديريت هيجانات منفى ارتباط دارد كه به نوبه خود ساز گارى مناسب با شرايط بيمارى را تحت تأثير قرار مىدهد (كاتز،

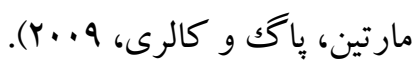
يافته ديخر يزوهش حاضر در زمينه ارتباط مستقيم ناكويى

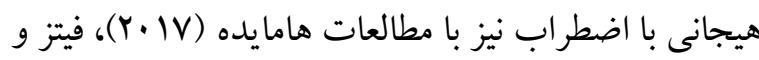

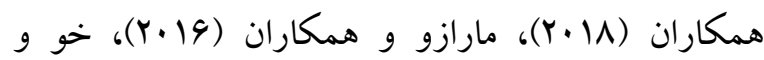

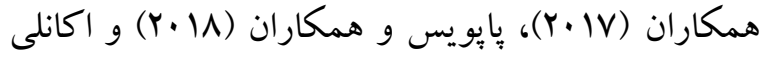

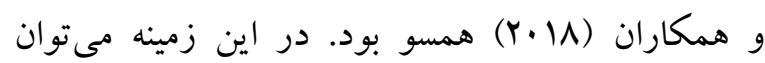
مطرح كرد كه ناگويى هيجانى كه با تفكر عينى، قدرت تجسم محدود، كاهش خياليردازىها و تمركز بر امور ساده، سطحى، عينى و خارجى مشخص مىشود، مى تواند به عنوان جايكزينى مكمل براى مكانيسم جبران تلقى

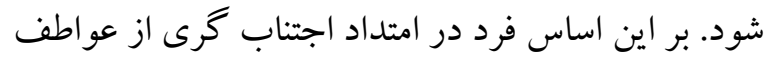
دردناك مبتنى بر تهييجهاى فيزيولوزيك از طريق تفكر عينى، هرجه بيشتر از دنياى درونى و واقعيتهاى نخر انكننده ذهنى فاصله مى گيرد و سدسازى خود در مقابل فشارهاى ناشى از اين عو اطف دردناكك را تكميل مى كند. شواهد نشان مىدهد اضطر اب مى تواند ناشى از حالتهاى وإِرونده رشد هيجانى باشد و بنابراين به فراخوانى ويز گىهاى ناگويى هيجانى منجر شود؛ به عبارت ديخر، افراد داراى علائم اضطرابى، هيجانهاى خود را كمتر مىيذيرند و بيشتر از راهبردهاى منع و سركوبخرى
جدول ץ نشان مىدهد كه ذهن آكاهى و آلكسى تايميا، اضطراب را به طور معنىدار،معنىدار بيشبينى مى كنند كه سهم هر يكك از اين متغيرها در تبيين $(P<\cdot / \cdot 1)$ واريانس اضطراب به ترتيب r او 9 درصد است.

مطالعه حاضر با هدف بررسى نقش ناكويى هيجانى و ذهن آكاهى در بيشينى افسردگى و اضطراب زنان مبتلا

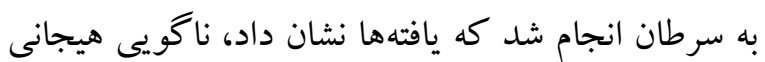
و ذهن آكاهى با افسردگى و اضطراب بيماران رابطه

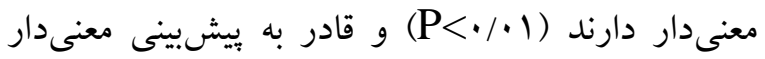
ميزان افسردگى و اضطراب اين بيماران مىباشند. نتيجه مطالعه حاضر در باب ارتباط مستقيم و معنىدار ناكويى هيجانى و افسردگى با مطالعات سونكايا و همكاران (Y.19) مارازو و همكاران (Y.19)، خو و همكاران (Y.IV)، צإيو يس و همكاران (YN) همسو بود. در تبيين اين يافته مىتوان گفتت، از آنجا كه توانايى ضعيف در شناسايى و ابراز هيجانها، ظرفيت هايين خياليردازى و تفكر عينى از ويز كىهاى اساسى ناكويى هيجانى است و سر كوبى عواطف، توانايى كاهش

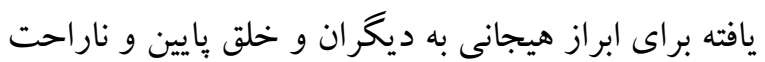

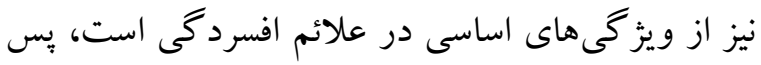
بين اين دو مؤلفه به لحاظ نظرى مىتوان ارتباط برقرار

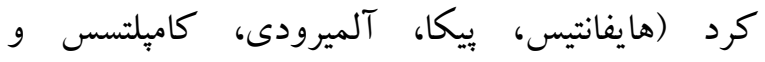
همكاران، (1) (Y). همجينين بسيارى از بيماران مبتلا به سرطان در شناخت و توصيف هيجانات خود ناتوان هستند. اين ناتوانى كه بهويزه در زمينه شناسايى هيجانات وضوح بيشترى دارد، باعث شكست فرد در تنظيم 
تر و سالم تر با محتو اهاى ذهن است (ايو انفسكى و مالهى، r..V كه افراد بهتر بتوانند مهارت هاى عادتى را از حالت تصلب خارج و با جهت دادن منابع بردازش اطلاعات به طرف اهداف خنثاى توجه، مانند تنفس يا حس لحظه، شرايط را براى تغيير آماده كنند؛ بنابراين، به كار كرفتن مجدد

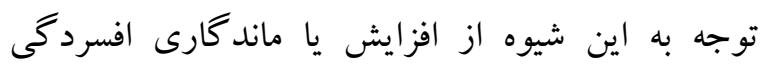
جلو گيرى مى كند و باعث مىشود جرخه هاى يردازش معيوب كمتر در دسترس قرار گيرند و شانس گستردگى افسردگى كاهش مىيابد (تيزدل و همكاران، .......

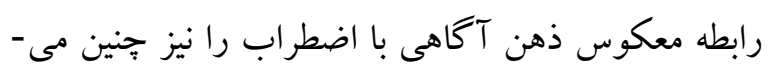
توان تبيين كرد كه بهبود اضطراب به دليل كاهش نشخوار ذهنى در اثر ذهن آكاهى صورت مى گيرد (راميل،

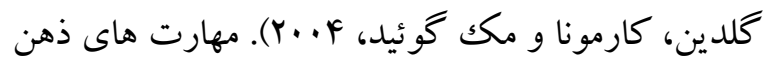

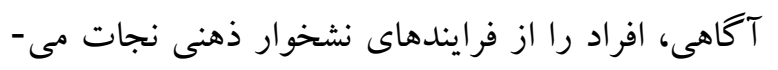
دهد و از باز گشت و بروز اضطراب جلو كيرى مى كند

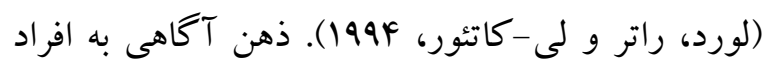
كمكك مى كند تا موقعيت هايى را كه باعث اضطراب و و استرس مى شود را شناسايى كنند، شناخت بهترى نسبت به خود يِيدا كنند، نقاط ضعف و قوت خود را بشناسند و سبس راهبردهاى مقابلهاى لازم براى كنترل اضطراب و استرس را دريافت كنند در نتيجه استرس و اضطراب بيوسته كاهش مى يابد (مستوبايشى، هوساكا و ايزومى،

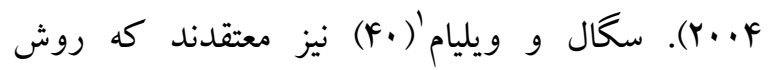
شناخت- درمانى مبتنى بر ذهن آكاهى، عنصر اصلى بالا بردن خودآكاهى لازم براى توانمندسازى و بِاسخهاى مطلوب در شرايط بحرانى براى جلو گيرى از تجربه
استفاده مى كنند (گرير، ساليس، تمل، لنيس و همكاران، $.(Y \cdot))$ از ديخر سو يافتهاى ئزوهش حاضر در زمينه ارتباط معكوس و معنىدار ذهن آكاهى با افسردگى و اضطراب با نتايج مطالعات لام و همكاران (Y.IV) (Y. (Y)، ماير و همكاران

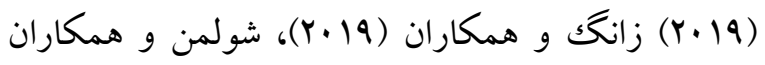
(Y.11) همكاران (Y.Mr)، حاجى سيد جوادى و و همكاران

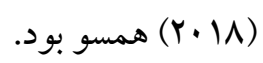
در تبين رابطه بين ذهن آكاهى با افسردگى، مىتوان

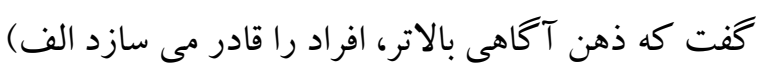
محتواهاى مخرب و الكوهاى عادتى ذهن را شناسايى كنند، ب) اين گونه اطلاعات را به شيوهاى غير قضاوتى مهى مورد يردازش قرار دهند تا توانايىشان براى انتخاب بين

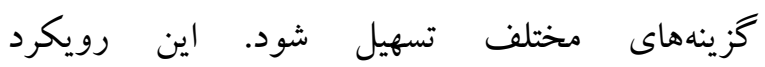
انعطاف يذيرى فعاليتهاى شناختى را افزايش مىدهد و نشخوار فكرى، بيش تعميمى در حافظه سر گذشتى و

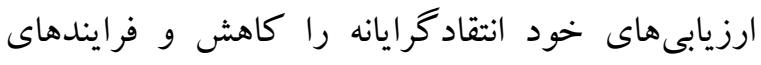
شناختى مفيد مانند مشاهده گرى غير قضاوتى محتواهاى ذهنى را افزايش مىدهد؛ بنابراين براى افت خلق افسرده مفيد واقع مى شود. هم جنين ذهن آكاهى نوعى كنترل فرايند توجه است كه منجر به ايجاد آكاهى فراشناختى مى شود. فرايندهاى فراشناختى اجازه توسعه نوعى حالت تمركز زدايى از افكار را فراهم مى كنند. در اين حالت افكار به جاى اينكه ضرورتاً بازنمايى هاى مستقيمى از واقعيت تعبير شود به عنوان رويدادهاى ذهنى كذرا ادراكك مى شوند. يكى از مزاياى جنين شيوه اى براى توجه كردن، ايجاد مفهومى براى توجه كردن، ايجاد مفهومى انعطاف يذيرانه از خود و برقرارى رابطهاى روان

1- Segal \& Wiliam 
increasing assertiveness among anxious students. J Urmia Univ Med Sci, 28(2),119129.

Besharat MA. (2007). Reliability and factorial validity of Farsi version of the 20-item Toronto Alexithymia Scale with a sample of Iranian students. Psychol Rep, 101 (1), 209-20.

Brown KW \& Ryan RM. (2003). "The benefits of being present: Mindfulness and its role in psychological wellbeing". Journal of Personality and Social Psychology,84, 822848.

Fietz J, Valencia N \& Silani G. (2018). Alexithymia and autistic traits as possible predictors for traits related to depression, anxiety, and stress: A multivariate statistical approach. Joumal of Evaluation in Clinical Practice, 24(4),901-908.

Ganz PA, Desmond KA, Leedham B, Rowland JH, Meyerowitz BE \& Belin TR. (2002). Quality of life in long-term, disease-free survivors of breast cancer. A follow-up study. Joumal of the National Cancer Institute, 94, 39-49.

Greer JA, Solis JM, Temel JS, Lennes IT, Prigerson HG, Maciejewski PK, et al. (2011). Anxiety disorders in long-term survivors of adult cancers. Psychosomatics, 52(2),417-23.

Haji Seyed Javadi T, Tajikzadeh F, Bayat H, Eshraghi N, Roshandel Z, \& et al. (2018). Comparison of Effectiveness of the Mindfulness-Based Cognitive Therapy and the Metacognition Treatment on Anxiety, Depression and Stress Among Breast Cancer Patients, 5(2),62-66.

Hamaideh SH. (2017). Alexithymia among Jordanian university students: Its prevalence and correlates with depression, anxiety, stress, and demographics. Psychiatric Care, 54(2),274 280.

Heidarirad F, Yarahmadi M, Heidarirad H, Shafeie M. (2018). Evaluation of Prevalence of Depression and Its Related Factors among Women with Breast Cancer Referred to the Radiotherapy Center of Tawhid Hospital of Sanandaj, Iran in 2017. Scientific Journal of Nursing, Midwifery and Paramedical Faculty. 4(2): 39-49.

$$
\begin{aligned}
& \text { اضطراب است و همواره به عنوان يكك محرك قوى } \\
& \text { دائمى بيش گيرنده عمل مى كند. }
\end{aligned}
$$

$$
\begin{aligned}
& \text { نتيجه كيرى } \\
& \text { بنابراين مطالعه حاضر نشان داد كه بين ذهن آكاهى و } \\
& \text { ناگويى هيجانى با افسردگى و اضطراب زنان داراى } \\
& \text { سرطان رابطه وجود دارد و اين دو متغير نقشى معنىدار در } \\
& \text { ييشبينى افسردگى و اضطراب اين زنان دارند. با توجه به } \\
& \text { يافته هاى مطالعه حاضر، مىتوان مهارتهاى كاهش } \\
& \text { ناگويى هيجانى و افزايش ذهن آكاهى را در كنار } \\
& \text { داروهاى درمانى به عنوان روان درمانى كه در اين زنان } \\
& \text { بحث بسيار مهمى است به ايشان ارائه داد تا واكنش } \\
& \text { مناسبى در شرايط برتنش داشته، از فشار موقعيت بكاهند } \\
& \text { و سلامت روحى و ساز گارى خود را افزايش دهند. از } \\
& \text { محدوديت هاى بزوهش حاضر مىتوان به استفاده از ابزار } \\
& \text { خود گزارشى (تاثير گذار در سو گيرى ارائه اطلاعات } \\
& \text { توسط آزمودنى ها) و در نظر نخرفتن متغيرهايى همجيون } \\
& \text { وضعيت اقتصادى-اجتماعى، ميزان برخوردارى از } \\
& \text { حمايت اجتماعى و خانوادگى بود كه اميد هست در } \\
& \text { بزوهش هاى بعدى مورد توجه يزوهش گر ان قرار گيرد. }
\end{aligned}
$$

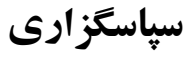

بدينوسيله از تمامى افرادى كه با حضور خود در اين يُزوهش ما را يارى كردند، سِاسخز ارى به عمل مى آيد. مطالعه حاضر بدون حمايت مالى خاصى انجام شده است

$$
\text { و با منافع نويسند گان ارتباطى ندارد. }
$$

\section{References}

Arab Ghaeni M, Hashemian K, Mojtabai M, Majd Ara E, Aghabeiki A. (2017). The effect of mindfulness training (MBSR) on the 
and Developmental Disorders, 1994, 24, 659685.

Marrazzo G, Sideli L, Rizzo R, Marinaro AM, Mule A, Marrazzo A, Cascia CLA, Barbera DLA. (2016). Quality of life, alexithymia, and defence mechanisms in patients affected by breast cancer across different stages of illness. Journal of Psychopathology, 22,141-148.

Mastsubayashi H, Hosaka T \& Izumi S. (2004). Increased depression and anxiety in infertile Japanese women resulting from lack of hasband support and feelings of stress. Gen Hosp Psyciarty, 2004, 26(5): 398-404.

Maudgal S, Han W, Shukla Mishra V. (2018). Alexithymia in Breast Cancer Patients and Their Sisters in Seoul. joumal of Global Oncology, 4(2).

Mayer B, Polak MG, Remmerswaal D. (2019). Mindfulness, Interpretation Bias, and Levels of Anxiety and Depression: Two Mediation Studies. Mindfulness. 10(1): 55-65.

Milligan F, Martinez F, Aal SHMA, Ahmed SA, Joby B, Matalam JS, Nair SS, De Leon Maxion A, Sayed S \& Melepeedikayil SS. (2018). Assessing anxiety and depression in cancer patients. British Journal of Nursin, 27(10),1823.

Motamedi M, Arefi M. (2018). Investigating Alexithymia among Women with and Without Thyroid Cancer in Isfahan . International Joumal of Body, Mind and Culture, 5(2), 104-11.

Nanni MG, Caruso R, Travado L, Ventura C, Palma A, Berardi AM, Meggiolaro E, Ruffilli F, Martins C, Kissane D, Grassi L. (2018). Relationship of demoralization with anxiety, depression, and quality of life: A Southem European study of Italian and Portuguese cancer patients. Psychooncology, 27(11),2616-2622.

Okanli A, Karabulutlu EY, Asi Karakaş S, Şahin Altun O, Yildirim N. (2018). Alexithymia and perception of illness in patients with cancer. European Joumal of Cancer Care (Engl), 27(3).

Perepelkin J, Antunes K, Boechler L, Remillard AJ, Mildenberger L. (2019). Providing
Holt J. (2002). Exploration of the concept of hop in the Dominican Republic. Joumal of Advanced Nursing. 32(5),1116-25.

Hyphantis T, Paika V, Almyroudi A, Kampletsas ED, \& Pavlidis N. (2011). Personality variables as predictors of early non-metastatic colorectal cancer patients' psychological distress and health-related quality of life: a one-year prospective study. The Joumal of Psychosomatic Research. 70 (5), 411-21.

Ivanovski B \& Malhi GS. (2007). The Psychological and Neurophysiological Concomitants of Mindfulness Forms of Meditation. Acta Neuropsychiatrica, 19, 76-91.

Jimenez-Fonseca P, Calderón C, Hemández R, Ramón Y, Cajal T, Mut M, Ramchandani A, Donnay O, Carmona-Bayonas A. (2018). Factors associated with anxiety and depression in cancer patients prior to initiating adjuvant therapy. Clinical and Translational Oncology, 20 (11),1408-1415.

Jitendra M, Meena M, Giti Ghoreishi A. (2017). Comparison of stress and coping styles in patients with cancer And healthy people. Joumal of Thought \& Behavior in Clinical Psychology, 11(45), 77-88.

Katz J, Martin AL, Page MG, Calleri V. (2009). Alexithymia and fear of pain independently predict heat pain intensity ratings among undergraduate university students. Pain Research and Managemen, 14(4),299-305.

Kaviani H, Seyfourian H, Sharifi V, Ebrahimkhani N. (2009). Reliability and validity of Anxiety and Depression Hospital Scales (HADS): Iranian patients with anxiety and depression disorders. Tehran Univ Med Sci, 67(5). [Persian].

Lam KFY, Lim HA, KuaEH, Griva K, Mahendran R. (2017). Mindfulness and cancer patients' emotional states: A latent profile analysis among newly diagnosed cancer patients. Mindfulnes. 9(2), 521-533.

Lord C, Rutter M \& Le Couteur A. (1994). Autism diagnostic interview-Revised: A revised version of a diagnostic interview for caregivers of individuals with possible pervasive developmental disorders. Joumal of Autism 
Shirin Z. (2018). The effects of mindfulness-based cognitive therapy on the dysfunctional beliefs, self- talk and self-management of cancer. Journal of Thought \& Behavior in Clinical Psychology, 12(48), 57-66.

Shulman B, Dueck R, Ryan D, Breau G, Sadowski I, Misri Sh. (2018). Feasibility of a mindfulnessbased cognitive therapy group intervention as an adjunctive treatment for postpartum depression and anxiety. Joumal of Affective Disorders, 235,61-67.

Sonkaya AR, Unal E, EmirC. (2019). The Relationship between Alexithymia and Depression in Patients with Multiple Sclerosis. EURASIAN JOURNAL OF MEDICAL INVESTIGATION, 3(2),169-172.

Teasdel JD, Segal ZV, Williams JMG, Ridgeway VA, Soulsby J \& Lau MA. (2000). Prevention of relapse in major depression by mindfulness based cognitive therapy. Consulting and clinical psychology, 2000, 68: 615-623.

Würtzen H, Dalton SO, Elsass P, Sumbundu AD, Steding-Jensen M, Karlsen RV, Andersen KK, Flyger HL, Pedersen AE, Johansen C. (2013). Mindfulness significantly reduces selfreported levels of anxiety and depression: results of a randomised controlled trial among 336 Danish women treated for stage I-III breast cancer. European Joumal of Cancer,49(6),1365-73.

Xu R, Yuan X, Tang Q. (2017). Alexithymia and negative emotions in cancer patients: Mediating effects of intrusive thoughts. Iranian Journal of Basic Medical Sciences, 42(12),1401-140.

Zhong M, Goh PH, Li D, Bao J, Xu W. (2017). Dispositional mindfulness as a moderator between perceived stress and psychological symptoms in Chinese digestive tract cancer patients. Joumal of Health Psychology.

Zhong M, Zhang Q, Bao J, Xu W. (2019). Relationships Between Meaning in Life, Dispositional Mindfulness, Perceived Stress, and Psychological Symptoms Among Chinese Patients With Gastrointestinal Cancer. mindfulness meditation for patients with depression and anxiety in a community pharmacy: A pilot study. Joumal of the American Pharmaceutical Association, 59(2),258-264.

Popovic D, Žipovski J, Brajković L, Jelinčić K. (2018). Depression and Anxiety among Women Suffering from Breast Cancer. Role of Individual's Defense Mechanisms and Alexithymia. Psycho-Oncology: Abstracts of the 20th World Congress of Psycho-Oncology, 29 October - 2 November 2018, Hong KongWiley and Sons. 150-150.

Ramel W, Goldin PR, Carmona PE, McQuaid JR. (2004). The effects of mindfulness meditation on cognitive processes and affect in patients with past depression. Cognitive Therapy and Research, 28(4), 433-455.

Roh D, Kim WJ, Kim CH. (2011). Alexithymia in obsessive-compulsive disorder. clinical correlates and symptom dimensions. Joumal of Nervous and Mental Disease, 199 (9), 6905.

Sadoughi M, Mehrzad V, Mohammad Salehi Z. (2017). The Relationship between Anxiety, Depression, and Quality of Life among Breast Cancer Patients in Seyedoshohada Hospital in Isfahan in 2016: The Mediating Role of Resilience. J Rafsanjan Univ Med Sci, 16(5): 395-408. [Persian].

Segal Z, Gemar M, Williams S. (1999). Differential cognitive response to a mood challenge following successful cognitive therapy or pharmacotherapy for unipolardepression. Joumal of Abnormal Psychology, 108(1), 310.

Segal ZV, \& Wiliam JM. (2002). Mindfulness-based cognitive therapy for depression: a new approach to preventing relapse. New York: Guilford press.

SeyedTabaee SR, Rahmatinejad P, Mohammadi D, Akbari V. (2018). Psychological Defense Mechanisms and Alexithymia in Cancer Patients. Aristotle University Medical Journal, 7(2), 141-150. 
19 نقش ناكويى هيجانى و ذهن آكاهى در بيشبينى افسردگى و اضطراب زنان مبتلا به سرطان

The Joumal of Nervous and Mental Disease ,207(1),34-37. 